\title{
Profile and generalist physician knowledge about neurology in emergency department: headache management
}

\author{
Perfil e conhecimento em neurologia do médico generalista no setor de emergência: \\ abordagem de cefaleias
}

Maren de MORAES E SILVA', Arnon César Brunet SCHULTZE², Beatriz Pyrich CAVALHEIRO², Lucas Filadelfo MEYER ${ }^{2}$, Juliana de Andrade FRONCHETTI ${ }^{3}$, Pilar Bueno Siqueira MERCER ${ }^{1}$, Maria Carolina Zavagna WITT ${ }^{1}$

\begin{abstract}
Background: Neurological complaints are frequent in emergency department routine. Among them, headache is a common disorder, which requires a certain degree of knowledge on Neurology because of its extensive differential diagnosis. Objective: To assess general practice physicians' level of knowledge about headaches, in addition to outlining the profile of professionals who attend in emergency departments, as well as the profile of their respective workplaces in terms of neurological approach. Methods: We included in evaluation physicians who attend emergency care units for adult public as general practitioners. A questionnaire was applied with questions regarding participants' general knowledge on headache, neurological approach, demographic profile, and workplace profile. Results: 159 physicians answered the questionnaire. The professionals' profile corresponded to recently graduated individuals (mean of 6.31 years). Knowledge about headache management was regular. Those who do not have any specialization or are not majoring a specialization were statistically significantly more confident in neurological patients care $(p=0.006)$. Only $18.24 \%$ reported access to Magnetic Resonance Imaging and $35.85 \%$ had no access to any type of neuroimaging. Conclusions: General practice physicians often do not feel confident when performing neurological exams, demonstrating low knowledge about the topic. The profile of professionals working in these departments is predominantly of newly graduates, which may affect in some way on care quality. There was also a lack of structure for adequate care.
\end{abstract}

Keywords: headache; knowledge; general practitioners; neurology; emergency medical services.

\section{RESUMO}

Introdução: Queixas neurológicas são frequentes na rotina de setores de emergência. Entre elas, a cefaleia é um distúrbio comum, que por seu diagnóstico diferencial amplo, exige certo grau de conhecimento em Neurologia. Objetivo: Avaliar o nível de conhecimento em cefaleias de médicos generalistas, além de traçar o perfil dos profissionais que atendem em setores de emergência nesta função, assim como de seus respectivos locais de trabalho em termos de abordagem neurológica. Métodos: Foram incluídos na avaliação médicos que atendem em unidades de pronto-atendimento para público adulto, na função de generalista. Um questionário foi aplicado com perguntas referentes ao conhecimento geral dos participantes sobre cefaleia, abordagem neurológica, perfil demográfico e perfil do local de trabalho. Resultados: 159 médicos responderam ao questionário. O perfil dos profissionais presentes na amostra correspondeu a indivíduos graduados recentemente (média de 6,31 anos). 0 conhecimento a respeito da abordagem de cefaleias foi regular. Aqueles que não possuem nenhuma especialização, nem estão cursando uma residência, se mostraram, de forma estatisticamente significativa, mais seguros no atendimento de pacientes neurológicos ( $p=0,006$ ). Apenas 18,24\% referiram ter acesso à Ressonância Magnética e 35,85\% não tiveram acesso a nenhum tipo de neuroimagem. Conclusão: Médicos generalistas frequentemente não sentem segurança ao realizar atendimento e exame neurológicos, demonstrando pouco conhecimento acerca do assunto. 0 perfil dos profissionais que atuam nesses setores é predominantemente de recém graduados, o que pode impactar de alguma forma na qualidade de atendimento. Verificou-se também falta de estrutura para um atendimento adequado.

Palavras-chave: cefaleia; conhecimento; clínicos gerais; neurologia; serviços médicos de emergência.

${ }^{1}$ Hospital da Cruz Vermelha Brasileira Filial Paraná, Curitiba PR, Brazil.

${ }^{2}$ Faculdades Pequeno Príncipe, Curitiba PR, Brazil.

${ }^{3}$ Faculdade Evangélica do Paraná, Curitiba PR, Brazil.

Maren de MORAES E SILVA ID https://orcid.org/0000-0001-7169-102X; Arnon César Brunet SCHULTZE (iD https://orcid.org/0000-0002-7576-0560; Beatriz Pyrich CAVALHEIRO (iD https://orcid.org/0000-0001-7303-2060; Lucas Filadelfo MEYER iD https://orcid.org/0000-0003-3622-2775; Juliana de Andrade FRONCHETTI (iD https://orcid.org/0000-0001-5754-6264; Pilar Bueno Siqueira MERCER (iD) https://orcid.org/0000-0002-28223092; Maria Carolina Zavagna WITT (iD) https://orcid.org/0000-0001-5234-9712

Correspondence: Maren de Moraes e Silva; Avenida Vicente Machado, 1310 - Batel; 80420-011 Curitiba PR, Brazil; E-mail: marenms@live.com Conflict of interest: There is no conflict of interest to declare.

Received on August 27, 2018; Received in its final form on October 02, 2018; Accepted on November 27, 2018. 
Neurological complaints are frequent in general practice physician's routine, especially those who work in emergency departments. Among them, headache is a very frequent disorder ${ }^{1}$, which requires a certain degree of knowledge on Neurology because of its extensive differential diagnosis. With high prevalence, it is estimated that each worker loses at least one workday per year due to incapacitating headache $^{2}$. Parallel to this, this symptom corresponds, in the United States, to the fifth cause of urgency and second most common neurological complaint admitted in this department $^{3}$. Adequate diagnoses and treatments make possible to reduce this impact on population quality of life 4 .

Classification in primary and secondary headache is important in initial evaluation. If primary headache is confirmed, prophylaxis should be improved in order to prevent future visits in emergency care units, while causes of secondary headache are potential emergencies, requiring prompt diagnosis and treatment. However, evidence indicates that there are divergences in diagnosis between generalists and neurologists ${ }^{3}$. Teaching about the topic in academia is unsatisfactory ${ }^{4}$, besides there is a lack of training regarding headache to graduated professionals. Previous findings have shown that patients with headache referral to neurologist often occurs without necessity, leading to resources wasting 5 .

Thus, it is therefore necessary to evaluate and create mechanisms to increase generalist's knowledge about headache in order to avoid undiagnosed cases, emphasizing the need for practice of continued medical education ${ }^{6}$. The objective of this study was to assess general practice physicians' level of knowledge about headaches, in addition to outline the profile of professionals who attend in emergency departments, as well as the profile of their respective workplaces in terms of neurological approach.

\section{METHODS}

The present study started after local Research Ethics Committee approval - CAAE 75384417.4.0000.5227. All evaluated individuals gave their permission to participate through signing an informed consent.

\section{Participants}

We included physicians who attend adult public emergency care units as general practitioners. Exclusion criteria were professionals who have specialization, residency or qualification as specialist in Neurology or Neurosurgery, or who are majoring these specializations. Professionals who exclusively attend pediatric patients were also excluded from evaluation.

\section{Testing application}

A cross-sectional study was carried out through questionnaire application with questions regarding general knowledge about headache, neurological management, and emergency units' general practitioners profile. The questionnaire was structured in four parts: informed consent, followed by demographic profile analysis and by multiple-choice questions subdivided in two stages. Initial 10 questions are about individual's perceptions regarding their knowledge and performance and then six practical questions about headache management in Emergency Care. Questions were elaborated by specialists. Regarding questions about headache clinical management, adequacy of responses was analyzed according to the National Protocol for Diagnosis and Management of Headache in Brazil Emergency Units, published by Headache Scientific Department of Brazilian Headache Society ${ }^{7}$ Questions used in questionnaire are presented in Appendix 1, available at www.limuneuro.com/questionsheadache. A pilot study was initially conducted with 10 physicians to evaluate applicability and test understanding. Questionnaires were applied in participants' native language (Brazilian Portuguese).

Questionnaires were applied online through Google Forms platform. Participants were recruited after contact with Regional Council of Medicine (CRM-PR) Department, which disclosed the research for doctors with an active membership to CRM-PR. Responses were collected for 60 days.

\section{Statistical analysis}

Responses frequencies were expressed as percentages, while continuous variables were expressed as means. Categorical variables were analyzed by chi-square test, while comparison of continuous variables was performed by Mann Whitney and ANOVA tests, when applicable. Statistical significance value was set at 0.05 .

\section{RESULTS}

\section{Profile of the doctor who works in emergency care}

One hundred and fifty-nine physicians answered the questionnaire. Participants mean age was $31.57 \pm 7.47$ years, with a female predominance ( $42.12 \%$ were men).

Average time since graduation is $6.31 \pm 7.25$ years, of which $32.70 \%$ are majoring residency or specialization and $40.25 \%$ are already specialists. Among the latter, the most frequent formations were Internal Medicine (13.83\%), General Surgery, and Orthopedics (both corresponding to 6.92\%). These professionals have worked in emergency department an average of $4.83 \pm 5.52$ years.

\section{Participants' self-judgment}

Participants were asked about their perceptions about own neurological skills. Responses distribution can be verified in Table 1.

When questioned about how often they feel need for Neurology specialist help, $37.74 \%$ of participants reported needing help often or frequently. Both time since graduation and time of work in emergency units did not correlate 
in a statistically significant way with perception of greater confidence in neurological care by participating physicians ( $p=0.92$ and $p=0.60$, respectively). However, those who do not have any specialization or are not majoring a residency were statistically significantly more confident in neurological patients care $(\mathrm{p}=0.006)$. Thirteen percent of interviewees affirmed never performing neurological physical examination, even in patients with suggestive nervous system involvement complaints.

\section{Structure for neurological care}

Participants were also asked about emergency units' structure. In $74.84 \%$ of them, there is no Neurologist on duty.

Table 1. Participant's judgment regarding their own knowledge.

\begin{tabular}{|c|c|c|}
\hline & Questions and options & Answers \\
\hline \multicolumn{3}{|c|}{ 1) How do you judge your knowledge in Neurology? } \\
\hline A & Excellent & $1.3 \%$ \\
\hline B & Good & $38.4 \%$ \\
\hline C & Regular & $54.7 \%$ \\
\hline D & Bad & $5.6 \%$ \\
\hline \multicolumn{3}{|c|}{ 2) How do you judge Neurology classes content in your college? } \\
\hline A & Excellent & $6.3 \%$ \\
\hline B & Good & $46.5 \%$ \\
\hline C & Regular & $36.5 \%$ \\
\hline D & Bad & $10.7 \%$ \\
\hline \multicolumn{3}{|c|}{$\begin{array}{l}\text { 3) Do you feel confidence performing complete neurological } \\
\text { physical examination? }\end{array}$} \\
\hline A & Yes & $23.9 \%$ \\
\hline B & No & $20.8 \%$ \\
\hline C & Partially & $55.3 \%$ \\
\hline \multicolumn{3}{|c|}{$\begin{array}{l}\text { 4) How do you judge your knowledge about Headaches } \\
\text { treatment? }\end{array}$} \\
\hline A & Excellent & $7.6 \%$ \\
\hline B & Good & $62.3 \%$ \\
\hline C & Regular & $29.5 \%$ \\
\hline D & Bad & $0.6 \%$ \\
\hline
\end{tabular}

When questioned about available materials for performing neurological physical examination, $49.06 \%$ reported having a reflex hammer, but only $15.72 \%$ had access to an indirect ophthalmoscope for suspected intracranial hypertension cases evaluation, while $47.17 \%$ reported having only a flashlight or have no material to assist neurological examination.

Regarding availability of imaging tests in units, $64.15 \%$ reported access to Computed Tomography, only $18.24 \%$ to Magnetic Resonance Imaging, and $35.85 \%$ did not have access to any type of neuroimaging.

\section{Knowledge assessment}

Of evaluated participants, only $31.45 \%$ knew the possibility of using chlorpromazine in a headache care context, while $63.52 \%$ reported prescribing routine opioids for migraine. Even when asked about medication, $32.70 \%$ of participants confused medications used for prophylaxis with abortive therapy.

Participants were also questioned about factors they considered as "red flags" to investigate secondary causes. Response distributions can be verified in Figure 1.

Still, when it comes to conduct evaluation, $16.98 \%$ of participants stated that they would perform lumbar puncture in patients with focal neurological signs prior to neuroimaging, $12.57 \%$ would have no restrictions before prescribing triptans for migraine with brainstem symptoms, and $25.53 \%$ did not know the possibility of migraine infarcts.

When questioned about management of chronic migraine with already known motor symptoms in all episodes, $62.26 \%$ stated that they would perform neuroimaging tests in all episodes, of which $75 \%$ would opt for Tomography as first choice.

\section{DISCUSSION}

Headache is a highly prevalent complaint in emergency units ${ }^{3}$, being important the presence of general

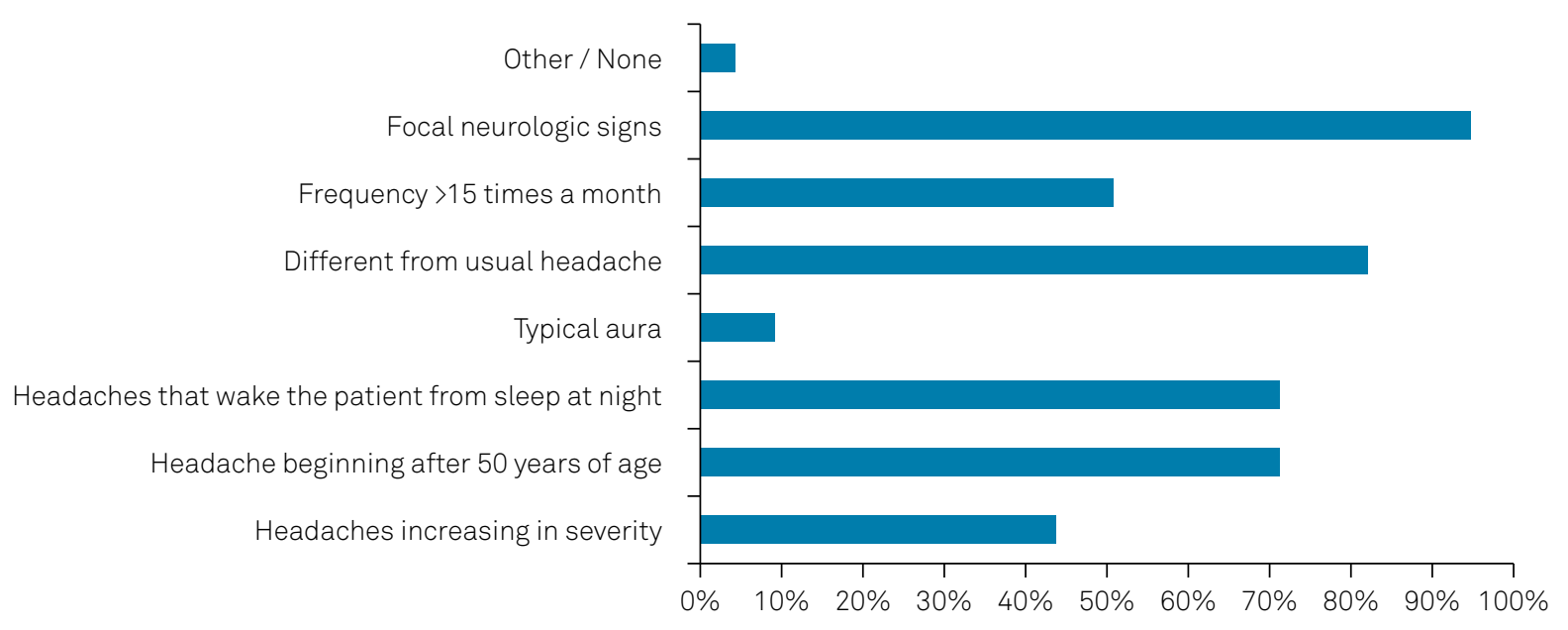

Figure 1. Answers for "red flags". 
practitioners with good knowledge about cephalalgia management in this sector.

Evaluation of medical knowledge regarding headache is scarce in literature, with only few studies addressing this issue, but in different populations, with no focus on emergency care. However, demographic data presented in this study are similar to previous findings in terms of gender distribution, reflecting a process of medicine "feminization". However, an important finding was in relation to prevalence of recently graduates, who seem to be the most frequent professional profile in these sectors, and may reflect on provided service quality. Previous studies have shown that more than half of newly graduated physicians work in emergency care, majoring medical residency or not ${ }^{9,10}$.

A possible justification for poor performance can be justified by lack of practice and clinical experience of newly graduated professionals. Previous studies have shown that this population is insecure when evaluating more complex clinical cases, which require specialized medical assistance ${ }^{11}$. In contrast, in our study, both time of service and time since graduation did not significantly influence the confidence of professionals. A remarkable result is that those who do not have any specialization and are not majoring residency have shown to be more confident in neurological patients care. This may be due to a greater contact with emergencies by these professionals when compared to specialist physicians.

An important issue to be addressed when considering the training of general practitioners is the "neurophobia" by graduation students and physicians ${ }^{12}$. Previous findings have shown that a large number of students do not feel confident when evaluating patients with neurological complaints, which are associated with "complex complaints"13,14, and may reflect the care given by newly graduated professionals. In addition, the absence of Neurology professionals in several hospitals is a contributory factor to disservice of qualified care.

Neurological semiology is based on detailed anamnesis and execution of an improved physical examination ${ }^{15}$. Professionals' lack of confidence regarding physical neurological examination, associated to lack of basic material to perform it, as evidenced by us, contributes to difficulty in performing accurate diagnoses. However, in addition to semiologic technique, an adequate care structure for medical assistance is essential, which seems to be in scarcity. Availability of neuroimaging tests presents an uneven distribution ${ }^{16}$. Finally, regarding imaging tests availability, magnetic resonance imaging was configured as the least accessible equipment, influencing posterior fossa pathologies investigation.

Regarding neuroimaging, in addition to paucity of these complementary exams when necessary for diagnostic elucidation, it is also important to evaluate another topic: the unnecessary exams request due to lack of preparation and lack of physical examination, which is evidenced by our study. Inadequate imaging tests solicitation can, in addition to causing health system financial burden ${ }^{4,17}$, bring harm to patients, with an increased risk of developing malignant tumors due to radiation exposure, in case of Computed Tomography ${ }^{18}$.

This study, however, has limitations. Physicians sampling is relatively small, and application form may generate a selection bias, since, possibly, those who are aware of their own difficulty in Neurology refuse to participate in test, with actual deficits of knowledge may be underestimated.

\section{CONCLUSION}

Although cases of headache are common in emergency room, most physicians do not feel confidence when performing neurological examination, showing lack of knowledge. Professionals' profile who works in these departments is predominantly of recent graduates, which may affect in some way on quality of care. There was also a lack of hospitals structure for a complete care, whose precariousness extends from simple physical examination instruments to imaging exams. In this context, it emphasizes importance of adequate Neurology teaching and the need of specialists' approved protocols for guidance. In addition, it is necessary to carry out periodic programs of continuing education, as well as to reinforce the hospitals' structures to improve neurological patients care.

\section{ACKNOWLEDGEMENTS}

We thank all profession colleagues that kindly participated in the study by responding to the questionnaire.

\section{References}

\footnotetext{
1. Stovner LJ, Hagen K, Jensen R, Katsarava Z, Lipton R, Scher $A$, et al. The global burden of headache: a documentation of headache prevalence and disability worldwide. Cephalalgia. 2007 Mar;27(3):193-210. https://doi.org/10.1111/j.1468-2982.2007.01288.x

2. Rasmussen BK. Epidemiology of headache. Cephalalgia. 2001 Sep;21(7):774-7. https://doi.org/10.1177/033310240102100708

3. Minen MT, Tanev K, Friedman BW. Evaluation and treatment of migraine in the emergency department: A review. Headache. 2014 Jul/Aug;54(7):1131-45. https://doi.org/10.1111/head.12399
}

4. Rodrigues MM, Souza JA, Barreiros H, Piovesan EJ, Kowacs F, Queiroz LP, et al. Distribution of "Brazilian headache specialists" Analyses of Brazilian Headache Society members. Einstein. 2007 Mar;5(1):48-50.

5. Braschinsky M, Haldre S, Kals M, lofik A, Kivisild A, Korjas J, et al. Structured education can improve primary-care management of headache: the first empirical evidence, from a controlled interventional study. J Headache Pain. 2016;17(1):24. https://doi. org/10.1186/s10194-016-0613-1 
RHD, Hamdar F. General practice physician knowledge about headache: evaluation of the municipal continual medical education program. Arq Neuropsiquiatr. 2009 Sep;67(3a):595-9. http://dx.doi. org/10.1590/S0004-282X2009000400004

7. Speciali JG, Kowacs F, Jurno ME, Bruscky IS, Carvalho JJF, Fantini FGMM, et al. Distribution of "Brazilian headache specialists" - Analyses of Brazilian Headache Society members. Einstein. 2007;5(1):48-50

8. Scheffer M. Demografia Médica no Brasil 2018. São Paulo, SP: FMUSP, CFM, Cremesp; 2018

9. Campos MCG, Senger MH. O trabalho do médico recém-formado em serviços de urgência. Rev Bras Clin Med São Paulo. 2013;11(4):1-5.

10. Purim KS, Borges LM, Possebom AC. Profile of the newly graduated physicians in southern Brazil and their professional insertion. Rev Col Bras Cir. 2016;43(4):295-300. http://dx.doi.org/10.1590/010069912016004006

11. Chehuen Neto JA, Sirimarco MT, Cândido TC, Ulhoa CM, Reis BP, Lima VM. Formação médica generalista: percepção do profissional e do estudante. HU Rev. 2014 Jan/Jun;40(1):13-23.

12. Jozefowicz RF. Neurophobia: the fear of neurology among medical students. Arch Neurol. 1994;51(4):328-9. https://doi.org/10.1001/ archneur.1994.00540160018003
13. Ansakorpi, H., Sumelahti, M. \& Kaasila, R. Medical students' experience of emotions and success in neurological studies What do they tell us?. BMC Med Education. 2017; 17(1):1-10 http:// doi:10.1186/s12909-017-0905-4

14. Matthias AT, Nagasingha P, Ranasinghe P, Gunatilake SB. Neurophobia among medical students and non-specialist doctors in Sri Lanka. BMC Med Education. 2013;13(1):164-71. https://doi. org/10.1186/1472-6920-13-164

15. Dantas AM. Exame de paciente com doença neurológica. Rev Bras Oftalmol. 2007;66(5):350-9. http://dx.doi.org/10.1590/S003472802007000500012

16. Araújo PNB, Colenci, R, Rodrigues SA. Mapeamento dos equipamentos e exames de diagnóstico por imagem no Estado de São Paulo. Tekhne Logos. 2016 Aug;7(2):121-35.

17. Benamore RE, Wright D, Britton I. Is primary care access to CT brain examinations effective? Clin Radiol. 2005 Oct;60:1083-9. https://doi. org/10.1016/j.crad.2005.05.010

18. Smith-Bindman R, Miglioretti DL, Johnson E, Lee C, Feigelson HS, Flynn M, et al. Use of diagnostic imaging studies and associated radiation exposure for patients enrolled in large integrated health care systems, 1996-2010. JAMA. 2012 Jun;307(22):2400-9. https:// doi.org/10.1001/jama.2012.5960
APPENDIX 1. QUESTIONNAIRE (NATIVE LANGUAGE).

PARTE 1 - TERMO DE CONSENTIMENTO LIVRE E ESCLARECIDO

PARTE 2 - PERFIL BIOPSICOSOCIAL

PARTE 3 - CONHECIMENTO EM NEUROLOGIA E CEFALEIAS

Instruções de preenchimento: assinalar com um X dentro dos parênteses a alternativa desejada para a resposta. 1) Como você julga seus conhecimentos em Neurologia? (assinale apenas 1 opção)

( ) Excelentes ( ) Bons ( ) Regulares ( ) Ruins

2) Como você julga os conhecimentos em Neurologia ensinados pela sua faculdade? (assinale apenas 1 opção)

( ) Excelentes ( ) Bons ( ) Regulares ( ) Ruins

3) Você sente segurança na realização do exame físico neurológico completo? (assinale apenas 1 opção)

( ) Sim ( ) Não ( ) Parcialmente

4) No Pronto Atendimento em que trabalha, há um Neurologista de plantão? (assinale apenas 1 opção)

( ) Sim ( ) Não

5) Com qual frequência você sente que necessitaria de ajuda de um especialista em Neurologia durante o seu plantão de Pronto Atendimento? (assinale apenas 1 opção)

( ) Sempre ( ) Com frequência ( ) Raramente ( ) Nunca

6) Como você julga seus conhecimentos na abordagem de Cefaleias? (assinale apenas 1 opção)

( ) Excelentes ( ) Bons ( ) Regulares ( ) Ruins

7) Quais materiais abaixo você costuma ter à mão para realização de exame físico neurológico durante seus plantões de Pronto Atendimento? (possível assinalar mais de uma opção)

( ) Martelo de Reflexos ( ) Diapasão ( ) Fundoscópio ( ) Algodão/Pincel ( ) Lanterna

( ) Alfinetes ( ) Nenhum dos citados ( ) Não realizo o exame 8) Quais dos seguintes exames você tem disponíveis nos locais nos quais trabalha em PA? (possível assinalar mais de uma opção)

( ) Tomografia computadorizada ( ) Ressonância Nuclear Magnética ( ) Nenhum

9) Com qual frequência você sente necessidade de solicitar exames de imagem para pacientes que vem ao atendimento com queixa de cefaleia? (assinale apenas 1 opção) ( ) Sempre ( ) Com frequência ( ) Raramente ( ) Nunca

10) Em quais situações você realiza o exame físico neurológico completo em pacientes de Pronto Atendimento? (assinale apenas 1 opção)

( ) Em todos os pacientes, independente da queixa

( ) Em todos os pacientes com queixas neurológicas

( ) Em nenhum paciente, solicito logo o exame de imagem

( ) Em nenhum paciente, solicito pedido de parecer do Neurologista

( ) Em nenhum paciente, não julgo este ponto importante

\section{PARTE 4 - QUESTÕES PRÁTICAS}

Instruções de preenchimento: assinalar com um $\mathrm{X}$ dentro dos parênteses a alternativa desejada para a resposta. 1) Pacientes apresentando-se em pronto socorro com migrânea clássica de forte intensidade, com sintomas resistentes aos analgésicos simples, AINES e triptanos. 
Assinale as opções que julga adequadas a serem tentadas como terapia abortiva: (possível assinalar mais de uma opção)

( ) opioides ( ) haloperidol ( ) clorpromazina ( ) antidepressivos tricíclicos

( ) betabloqueadores ( ) nenhuma das anteriores/outras

3) Assinale, abaixo, quais sinais e sintomas que você julga como indicativos de necessidade de investigação adicional para causas secundárias de cefaleia: (possível assinalar mais de uma opção)

( ) Cefaleia de forte intensidade ( ) Cefaleia de início em idosos ( ) Cefaleia que acorda o paciente a noite ( ) Escotomas cintilantes precendendo a cefaleia ( ) Cefaleia crônica com mudança no padrão da dor ( ) Cefaleia hemicraniana ( ) Fotofobia ( ) Cefaleia >15 vezes ao mês ( ) Alterações ao exame físico neurológico ( ) Nenhuma das acima

4) Paciente apresentando-se com cefaleia de forte intensidade. Em quais casos indicaria uma punção lombar? (possível assinalar mais de uma opção)

( ) Caso apresente apenas febre associada, já indicaria

( ) Caso apresente apenas rigidez de nuca, já indicaria

( ) Caso apresentasse alteração focal ao exame físico neurológico, antes de exame de imagem

( ) Caso apresentasse alteração focal ao exame físico neurológico, após exame de imagem
( ) Caso apresentasse rebaixamento do nível de consciência

( ) Nenhuma das acima

5) Paciente vem ao atendimento com queixa de cefaleia de forte intensidade, solicitando medicação abortiva de crise. Refere que este episódio é igual aos que sempre tem - possui diagnóstico de migrânea com aura de tronco encefálico. Quais drogas das listadas abaixo são contraindicadas neste caso? (possível assinalar mais de uma opção)

( ) analgésicos simples ( ) antiinflamatórios não esteroidais ( ) triptanos ( ) ergotamínicos

( ) haloperidol ( ) clorpromazina ( ) opioides ( ) nenhuma das listadas, todas podem ser utilizadas

6) A respeito da seguinte afirmativa, assinale verdadeiro ou falso: "A migrânea pode ser complicada por isquemia de tecido encefálico”. (assinale apenas 1 opção)

( ) Verdadeiro ( ) Falso

7) Paciente vem ao atendimento em decorrência de crise de migrânea de forte intensidade, cursando com hemiparesia a esquerda. Refere que possui crises de migrânea já há 10 anos, e que todas possuem características semelhantes ao quadro atual, com déficit motor. Qual exame complementar você indicaria, na sala de emergência, nesta situação?

( ) Tomografia computadorizada ( ) Ressonância Magnética ( ) Não faria exames de imagem 